\title{
Study of Sulphone Resistance in Leprosy Patients in India
}

\author{
P. M. TAYLOR, C. J. G. CHACKO AND C. K. JOB \\ Schieffelin Leprosy Research Centre, Karigiri, \\ North Arcot, S. India 632106
}

\begin{abstract}
Studies were undertaken to confirm the occurrence of resistant strains of Myco. leprae in leprosy patients who fail to respond to treatment with dapsone. In the first 3 years, 39 patients who had highly active disease despite a long history of treatment were selected from our outpatient clinic. A suspension of bacilli from an active lesion was injected into the foot pads of a group of normal CBA mice. The mice were then fed varying doses of dapsone in the diet for several months. At harvest, multiplication had occurred in the presence of high doses of dapsone in 12 , at low dosage in 7 and only in the control group in 14. There were 6 failed experiments. This demonstrates that 19 patients harboured Myco. leprae to some extent resistant to dapsone.

Observations on the clinical manifestations and subsequent progress are made and compared with reports from other centres.
\end{abstract}

Leprosy patients who fail to respond to adequate treatment with sulphones have been well known in India for several years (personal observations). However, they were not documented due to lack of laboratory evidence to confirm these findings beyond reasonable doubt. Now that laboratory facilities to grow the organisms in the foot pads of mice are readily available, studies were undertaken to find out and report the occurrence of resistant strains of Mycobacterium leprae in India.

Several papers on the emergence of dapsone resistant Myco. leprae have been clearly presented from other countries (Adams and Waters, 1966; Pettit and Rees, 1964; Rees, 1967; Jacobson, 1973). Certain patterns of clinical presentation and bacteriological findings of these patients have been evident. In this study it is aimed to identify the sulphone resistant patients and to record their clinical profile and bacteriological findings with a view to elucidate if possible some of their behaviour.

\section{Material and Methods}

During the first 3 years of this study cases were selected by careful screening of patients attending the out-patient treatment unit at this centre. The patients report voluntarily for management or are referred for special study from different

* Received for publication 14 August, 1975. 
parts of the country. In addition 3 were referred from village clinics in our control area. Thirty nine cases with features suggestive of sulphone resistance were selected. They were selected on the basis of having a high Bacteriological Index despite a fairly long history of treatment with dapsone be it inadequate or irregular. Patients developing histoid features, or an acute exacerbation while on apparently adequate treatment were also chosen. These patients were classified on the basis of clinical and bacteriological examination and confirmed by histopathological examination of skin biopsies in 31 cases.

A careful clinical history including past schedule of DDS treatment and reactional episodes was recorded in each case. Skin smear studies with estimation of Bacteriological and Morphological Indices were done. The lesion with the highest Bacteriological Index and Morphological Index was biopsied for histology and a portion of the skin biopsy was used for animal experiments using normal CBA mice. The processing of the tissue for animal experimental studies was done as reported in our previous studies (Job, 1970; Job et al., 1974). The animals were divided into 4 groups of 6 animals each. One group was fed a diet containing $0.01 \%$ of dapsone, another $0.001 \%$ of dapsone, the third $0.0001 \%$ of dapsone, and the fourth group on normal diet without drugs. At the end of 6,8 and 10 months 2 animals from each of the groups were sacrificed and their foot pads were harvested and multiplication of Myco. leprae assessed.

All patients continued as out-patients after their presenting symptoms subsided. We could not therefore control their subsequent course of treatment sufficiently to correlate this with the results of the experiment in mice. Some of the patients because of the severity of their disease, with chronic reaction or advanced relapse, were started on clofazamine directly after the test was over. Others were continued on dapsone 50 or $100 \mathrm{mg}$ daily until the result of the test was available

\section{Results}

In the experiments conducted on 39 patients, 6 were considered to be failures. That is, there was no multiplication of Myco. leprae in the foot pads of any mice. Fourteen strains were highly sensitive to dapsone, multiplication being inhibited in all 3 groups fed dapsone in the diet, but with growth in the control group of mice. In 7 experiments there was growth of Myco. leprae in mice fed $0.001 \%$ and $0.0001 \%$ dapsone in the diet, though growth was inhibited in mice fed $0.01 \%$ dapsone. In 12 experiments there was multiplication in the foot pads of mice in all groups and therefore the strains of Myco. leprae concerned have become resistant to dapsone (Table 1 ).

Clinically, there were among the 39 patients, 31 of lepromatous leprosy, 4 with borderline lepromatous leprosy and 4 with histoid nodules (Ridley and Jopling, 1966; Wade, 1963). These were evenly distributed among the groups in the experiment as shown in Table 2. In all but 3 cases it is noted that there were active discrete lesions superimposed on old diffuse lepromatous disease. These lesions are described as nodules in 10 of the resistant cases, 12 of the sensitive cases, 6 of the partially resistant and in 3 in which there was no growth. In 2 of the resistant and sensitive groups, and one of the no growth group the lesions are described as raised erythematous lesions or plaques (see Table 3 ).

The Bacteriological Index (Ridley, 1958) of these lesions was particularly high compared to the surrounding skin and tended to have a raised percentage of solid 


\section{TABLE 1}

The growth of Myco. leprae in mice fed varying doses of dapsone

\begin{tabular}{cccccc}
\hline \multicolumn{5}{c}{ Growth of bacilli in mice fed on } \\
$\begin{array}{c}\text { Number } \\
\text { of patients }\end{array}$ & $\begin{array}{c}\text { Control } \\
\text { diet }\end{array}$ & $\begin{array}{c}0.0001 \% \\
\text { DDS in diet }\end{array}$ & $\begin{array}{c}0.001 \% \\
\text { DDS in diet }\end{array}$ & $\begin{array}{c}0.01 \% \\
\text { DDS in diet }\end{array}$ & $\begin{array}{c}\text { DDS } \\
\text { sensitivity }\end{array}$ \\
\hline 12 & + & + & + & + & Resistant \\
7 & + & + & + & 0 & $\begin{array}{c}\text { Partially resistant } \\
\text { Sensitive } \\
14\end{array}$ \\
6 & + & 0 & 0 & 0 & Unknown (failed \\
experiment) \\
Total & & 0 & 0 & 0 & \\
39 & & & & & \\
\hline
\end{tabular}

TABLE 2

Distribution of types of leprosy among patients tested for dapsone (DDS) resistance

\begin{tabular}{lccc}
\hline & \multicolumn{2}{c}{ Number of patients presenting with: } \\
$\begin{array}{c}\text { DDS } \\
\text { sensitivity }\end{array}$ & $\begin{array}{c}\text { Histoid } \\
\text { leprosy }\end{array}$ & $\begin{array}{c}\text { Lepromatous } \\
\text { leprosy }\end{array}$ & $\begin{array}{c}\text { Borderline } \\
\text { lepromatous } \\
\text { leprosy }\end{array}$ \\
\hline Resistant & 1 & 10 & 1 \\
Partially & 2 & 4 & 1 \\
resistant & 1 & 12 & 1 \\
Sensitive & - & 5 & 1 \\
\hline Unknown & & & \\
\hline
\end{tabular}

TABLE 3

Nature of presenting skin lesions among patients tested for dapsone resistance

\begin{tabular}{cccc}
\hline & \multicolumn{2}{c}{ Number of patients presenting with: } \\
$\begin{array}{c}\text { Dapsone } \\
\text { sensitivity }\end{array}$ & Nodules & $\begin{array}{c}\text { Infiltrated } \\
\text { plaques }\end{array}$ & Not stated \\
\hline Resistant & 10 & 1 & 1 \\
Partially & 6 & - & 1 \\
resistant & 12 & 2 & - \\
Sensitive & 3 & 2 & 1 \\
Unknown & 3 & & \\
\hline
\end{tabular}

rod forms. The distribution of these findings is demonstrated in Table 4. The higher Morphological Index (Waters and Rees, 1962) tended to occur with greater frequency in resistant cases (Table 5).

In most cases the patients mentioned the places where they had received treatment previously and did not know either the drugs or dosage they were given. It is presumed that recognized leprosy centres were using sulphones from 
TABLE 4

Bacteriological Index (BI) of the lesion biopsied among patients tested for dapsone resistance

\begin{tabular}{|c|c|c|c|c|c|c|}
\hline \multirow{2}{*}{$\begin{array}{l}\text { Dapsone } \\
\text { sensitivity }\end{array}$} & \multirow[b]{2}{*}{ BI 2} & \multicolumn{4}{|c|}{ Number of patients: } & \multirow{2}{*}{$\begin{array}{l}\text { Not } \\
\text { available }\end{array}$} \\
\hline & & BI 3 & BI 4 & BI 5 & BI 6 & \\
\hline Resistant & - & 1 & - & 4 & 4 & 3 \\
\hline $\begin{array}{l}\text { Partially } \\
\text { resistant }\end{array}$ & - & - & 4 & 2 & 1 & - \\
\hline Sensitive & - & - & 1 & 5 & 3 & 5 \\
\hline Unknown & - & 1 & 2 & 1 & 1 & 1 \\
\hline
\end{tabular}

TABLE 5

Morphological Index of suspension used for foot-pad inoculation

\begin{tabular}{lcccc}
\hline $\begin{array}{l}\text { Dapsone } \\
\text { sensitivity }\end{array}$ & \multicolumn{4}{c}{ Morphological Index } \\
& 0 & $1-5$ & $6-10$ & $11-15$ \\
\hline Resistant & 1 & 4 & 6 & 1 \\
Partially & & & & \\
resistant & - & 5 & 2 & - \\
Sensitive & 2 & 9 & 2 & 1 \\
Unknown & 4 & 2 & - & - \\
\hline
\end{tabular}

1960 onwards. Some patients were quite specific as to the maximum dose they had received and could give many more details. The case records of a few were available for assessment.

A frequently recurring feature in the history of these patients was the occurrence of chronic ENL reaction. This was elicited from 6 patients from whom resistant strains of Myco. leprae, were isolated, also from 2 with partially resistant Myco. leprae, 5 with dapsone sensitive infection and 4 of the group which had no growth in mice. This complication of the disease had a marked effect on the treatment in every case, causing dapsone to be given either in low dosage or intermittently.

Of the cases harbouring dapsone resistant organisms 5 claimed to have been taking treatment regularly. Four of these had been having treatment for 25 years or more. The fif th had been on low doses of dapsone because of frequent episodes of reaction and had treatment for less than 5 years.

Among patients harbouring organisms resistant to low doses of dapsone, 5 had been taking treatment irregularly. The range of time from start of treatment to the time of test was from 4 to 30 years. Two patients taking treatment regularly also carried organisms resistant to low doses of dapsone. The duration of treatment before test in these patients was 6 and 11 years.

In patients carrying dapsone sensitive organisms 11 had been irregular with their treatment over a time range of 4 to 14 years before the test. Three had been regular with treatment over a period of 15 to 35 years.

In the failed experiment group similarly 4 patients had been irregular with 
treatment, the duration of treatment before relapse being 9 to 14 years. Two patients had been regular with treatment for 15 and 20 years.

Of particular interest is a patient who had been taking treatment for 35 years but had discontinued 4 years after becoming skin smear negative. Two and a half years later he relapsed and the organisms were found to be still dapsone sensitive by the test in mice and subsequent progress. On the other hand a patient taking treatment for 6 years and discontinuing on the attainment of smear negativity relapsed 6 months later with organisms partially resistant to dapsone. A third patient who has been an inmate in a leprosy home since 1940 attained smear negativity in 1961. Even from that time he was consistently getting $50 \mathrm{mg}$ dapsone daily. Twelve years later he relapsed with histoid lesions and the organisms recovered were resistant to dapsone.

\section{Follow Up}

Patients who are shown to have dapsone resistant Myco. leprae are treated with $100 \mathrm{mg}$ clofazimine daily. Of the 12 resistant, 2 are lost to follow up. Ten are showing satisfactory resolution of their lesions and a significant reduction in the Bacterial Index on skin smear of the appropriate sites and a zero Morphological Index.

Of patients with Myco. leprae partially resistant to dapsone, 3 have been lost to follow up. Three are being treated successfully with clofazimine, as is the one case who is now taking $100 \mathrm{mg}$ dapsone daily.

In the group with dapsone sensitive infection, 7 are still available to follow up. They are all either on dapsone $50 \mathrm{mg}$ or $100 \mathrm{mg}$ daily. Three are making satisfactory progress. Three are making very slow, or no progress, and one has definitely deteriorated and is still developing new lesions though on $100 \mathrm{mg}$ dapsone. This latter case is being retested.

In the failed group 3 are still being followed up. One case is taking $100 \mathrm{mg}$ clofazimine daily; one, $100 \mathrm{mg}$ dapsone daily and one is on $50 \mathrm{mg}$ dapsone daily. All are making satisfactory progress.

\section{Discussion}

While it is apparent from this study that there are no particular clinical features that will identify patients harbouring dapsone resistant Myco. leprae, this can be proved in cases of relapsed leprosy, particularly in cases with active nodules and high bacterial positivity, by using the mouse foot pad technique for culturing the organism. It was observed that the nodules may develop quite suddenly over the course of 1 or 2 months. It is hard to imagine that this could happen if the organism is multiplying at its usual rate of once in 12 to 21 days. It is fascinating to consider what factors may be involved in accelerated multiplication in localized lesions in patients who have little or no immunity to the infection.

The result of the test in the mouse foot pad depends very much on a suitable representative biopsy being made of the most active looking lesion. It is possible that the case still deteriorating on dapsone did not have a representative lesion biopsied in his first test.

It is noted that the highest dose of dapsone we used in the mouse experiments was $0.01 \%$ which has been shown (Ellard et al., 1971) to correlate closely with the usual maximum therapeutic dose in man of $100 \mathrm{mg}$ dapsone daily. Those with 
organisms resistant at the lower doses may yet respond to $100 \mathrm{mg}$ dapsone daily, at least for a time.

The patients on clofazimine who know they are resistant are very careful now to take their treatment regularly. The reason some may not be doing well in the sensitive group may be that they are lulled by the result of the test into a false sense of security, and are still being irregular in their treatment. They are still very much at risk for developing resistance because of the prolonged persistance of viable bacilli.

The results show a tendancy for relapse to be earlier if treatment is irregular. With regular treatment relapse tends to be delayed particularly if the dose of sulphone is high. However, even $50 \mathrm{mg}$ dapsone daily is no protection against relapse with dapsone resistant organisms. Also skin smear negativity is an inadequate test for cure of lepromatous leprosy, for even af ter a prolonged course of apparently successful treatment a patient may relapse then with sulphone resistant organisms.

The association with reactive episodes is significant only in that it has affected the dose and regularity with which dapsone is prescribed. Now effective anti-inflammatory drugs are available to control reactive episodes, it is no longer necessary to reduce or stop dapsone treatment.

The finding of dapsone resistance among a proportion of patients with uncontrolled or relapsed lepromatous infection is very similar to that reported from other centres. The clinical appearance, past history and subsequent response to therapy is also consistent with what has been observed elsewhere. (Pearson, Rees and Waters, 1975; Jacobson, 1973; Pettit et al., 1966). It is emphasized that the sooner a patient's disease can be controlled with adequate therapy the less risk there is of developing resistance. It may be necessary to consider combined therapy if this complication is to be avoided.

\section{Acknowledgements}

We wish to thank Mr Samuel Joseph for his painstaking care in conducting the animal experiments. The project was supported by The Leprosy Mission to whom we also express our sincere appreciation.

\section{References}

Adams, A. R. D. and Waters, M. F. R. (1966). Dapsone resistant lepromatous leprosy in England. Br. med. J. 2, 872 .

Ellard, G. A., Gammon, P. T., Rees, R. J. W. and Waters, M. R. F. (1971). Studies on the determination of the minimum inhibitory concentration of dapsone against Myco leprae. Lepr. Rev. 42, 101.

Jacobson, R. R. (1973). Sulphone resistant leprosy, Etiology and treatment in the United States. Int. J. Lepr. 41, 684.

Job, C. K. (1970). Bacteriological and pathological study of leprosy lesions in the foot pads of mice. Indian J. Path. Bact. 13, 109.

Job, C. K., Chacko, C. J. G., Verghese, R. and Padam Singh, S. (1974). Enhanced growth of $M$. Reprae in the foot pads of Hiy mectomized irradiated mice. Lep. Ind. 46, 216.

Pearson, J. M. H., Rees, R. J. W. and Waters, M. F. R. (1975). Sulphone resistance in leprosy. A review of one hundred proven clinical cases. Lancet 2, 69.

Pettit, J. H. and Rees, R. J. W. (1964). Sulphone resistance in leprosy. An experimental and clinical study. Lancet 2, 673.

Pettit, J. H., Rees, R. J. W. and Ridley, D. S. (1966). Studies on sulphone resistance. Detection of cases. Int. J. Lepr. 34, 375. 
Rees, R. J. W. (1967). Drug resistance of M. leprae particularly to DDS. Int. J. Lepr. 35, 625. Ridley, D. S. (1958). Therapeutic trials in leprosy using serial biopsies, Lepr. Rev. 29, 45.

Ridley, D. S. and Jopling, W. H. (1966). Classification according to immunity. Int. J. Lepr. 34, 255.

Wade, H. W. (1963). The histoid variety of lepromatous leprosy. Int. J. Lepr. 31, 255.

Waters, M. F. R. and Rees, R. J. W. (1962). Changes in this morphology of M. leprae in patients under treatment. Int. J. Lep. 30, 266. 